\title{
Using Video Technology to Address Boys' Literacy Gap and Connect the Male Voice in Gender Dynamics
}

\author{
Carol-Ann Lane \\ Western University, Canada
}

\begin{abstract}
Boys' lower literacy level is worldwide and needs attention. According to the world PISA findings "girls outperform boys in reading in every PISA country. In OECD [41] countries, the average gender gap is 39 score points, or over half a proficiency level". The focus of this research is to understand boys' interests in their use of game technologies that have potential for literacy value. A sub-focus points to feminism maturation which has occurred or is forthcoming. For this reason, there is a concern to identify power relations which exist and bring into perspective a more balanced view of gender without marginalizing the male voice. Examination of the literature, practice and positioning of masculine stereotypical males in emerging gender power dynamics may contribute to the understanding of boys' literacy. The research question is to what extent multiliteracies practiced through computerized games manifest themselves in gender equality in secondary schools?
\end{abstract}

\section{Introduction}

This paper addresses social inequity experienced by masculine stereotypical male high school students for literacy practices. For the purposes of this research, I will draw on Bourdieu's [9] definition of masculine stereotypes as "sports in modern societies, and most especially those which most tend to produce the visible signs of masculinity, and to manifest and also test what are called manly virtues, such as combat sports" (p. 51). The research will explore the positioning of masculine stereotypical males in emerging gender power dynamics which may contribute to the understanding of boys' literacy practices.

Widespread media and concern have been raised over the disadvantaged boy syndrome, which has continued to fuel debates between feminists and male activists, creating an endless dichotomy. According to the world PISA findings "girls outperform boys in reading in every PISA country. In OECD [41] countries, the average gender gap is 39 score points, or over half a proficiency level". My research stems from indicators such as, an Ontario study on gender inequality by Brochu, Gluszynski, \& Knighton [8], reporting for the Programme for International Student Assessment (PISA) in 2009 (results for 2012 available Dec. 2013), showed "the average score for 15 year old students for combined reading indicated female students outperformed males by 37 points" (pp.74-75). My research focuses on understanding boys' interests in their daily lives through the use of video game technologies which have potential for literacy. Furthermore, there is a point at which feminism maturation has occurred or is forthcoming. For this reason, my concern is about identifying power relations which exist and bring into perspective a balanced view of gender without marginalizing the male voice. Investigation of the literature, practice and positioning of masculine stereotypical males in emerging gender power dynamics may contribute to the understanding of boys' literacy practices. The research question is to what extent multiliteracies practiced by masculine stereotypical males through computerized games manifest themselves in gender equality in secondary schools?

\section{Context of Issue}

Shortcomings exist in literature regarding masculine stereotypical males and how they interact with their external environment to translate to successful literacy. There is a major shortfall in the literature as noted by a number of scholars. Akkerman et al. [2], Gros [23], and Huizenga et al. [27] recognize "no research...actually documents a link between video game playing attention skills, and success in academic performances or specific occupations" (p. 30). This lack of research is the result of misperception of literacy content in 
computerized games dominated by violence and misogyny which may influence a variety of social issues that come from their use. Current literature on boys and literacy practices relating to video gaming is advocated by Gee [21] but scholars have limited research in this area due to the debates surrounding themes of misogyny (see for example, Alexander [3]; Sanford and Madill [44] and [45]; and Steinkuehler [51]. Ajayi [1] and Apperley and Beavis [5], share this similar claim with Alexander [3] who confirms "connection between gaming and violence... (do video games promote sexist images of women, or men" (p. 38). This study explores video game practices among varying types of boys to help bridge their out-of-school practices with in-school literacy practices and promote gender equity. The New London Group [40], postulated multiliteracy pedagogy is "increasingly multimodal-in which written linguistic modes of meaning are part...of visual, audio and spatial patterns of meaning" (p. 5). My research topic explores boys' interests (from a standpoint of a masculine stereotypical male) with multiliteracy elements such as video games to foster successful literacy. I will focus on understanding boys' use of video game technologies to bridge their out-of-school interests with in-school literacy practices.

\section{Ontology}

My ontological assumption of how the world is made up and how things exist in society is constructivism; different people existing in the world construct reality. Based on my beliefs, reality is being shaped and constantly changing based on the political landscape, cultural landscape, perspectives, values and experiences of people who live and interact with each other in society. This is underpinned by a critical paradigm. I believe in knowledge transforming and peoples' realities being shaped constantly by these interactions within social contexts. Within this interpretive social paradigm, I assume relativism. Guba and Lincoln [24], describe relativism as "realities are apprehendable in the form of multiple, intangible mental constructions, socially and experientially...shared among many individuals and even across cultures)...constructions are alterable, as are their associated 'realities"' (p. 110). Therefore, reality is subjective, dynamic and not static. To gain insight on how humans interact in society and how they inform their decisions I need to understand the contextual meaning in their lives as they place themselves subjectively in the world and connect with each other. In fact, Neuman [39] highlights this by indicating "values are an integral part of social life: no group's values are wrong, only different" (p.105). It is this difference of multiple perspectives, sometimes competing due to self-interested individuals which sometimes causes disharmony in the world. Self-interested individuals can exhibit what Bourdieu calls a symbolic power (Swartz [52]). This disharmony influenced by symbolic power exists as people differ in opinions and views of reality which causes cognitive dissonance (Piaget [43]; Festinger [15]). In order for each person to develop equilibrium or harmony they need to develop reasoning powers to make sense of the world and the choices they make.

I will review various theories to bridge any disconnects or gaps that may exist in current discourse (especially tensions arising from critics of poststructural feminism and male studies) to foster gender equity and video game literacy. This is salient to my research as I explore how boys' literacy may be influenced by exposure to masculine stereotypical and nonmasculine stereotypical preferences fostered by social constructions of gender and video game usage including collaborative play/activity based learning. I believe due to the backlash theory there is a lack of literature surrounding a focus on boys and their use of video games (out of school and in school) to improve literacy performance. Some studies focused on outside interests but relating to leisure reading and computer usage rather than using video games to bridge the literacy back into schools (see for example, Love and Hamston [33]).

To better understand the cause of the boys' literacy gap, an identification of which boys representing that gap needs to occur for any constructive positive research achievements to be made. As I explore my investigation of boys' literacy, my interest is informed by my theoretical lens as a feminist poststructuralist and will critically examine and challenge current discourse surrounding gender equity. To further inform my research I will use cognitive dissonance (disequilibrium) to rebuild any existing disconnects (feminism movement or resistance to video gaming) and examine out-ofschool video game literacy activities to in-school literacy practices.

With respect to gender, biological determination of male and females is binary in a medical sense based on $\mathrm{x}$ and $\mathrm{y}$ chromosomes 
for males and $\mathrm{xx}$ chromosomes for females. According to the Centre for gender-based biology in the University of California [10]

"In humans (and in mammals in general), sex is determined when the undifferentiated and bipotential embryonic gonad (the genital ridge), becomes either a testis or an ovary" [Differences of] "sexual development encompass a very large spectrum of phenotypes, from minor malformations of the genitalia (hypospadias, cryptorchidism, hypertrophy of the clitoris) to sexual ambiguity. Taken altogether, these anomalies have an estimated frequency of $0.5 \%$ to $1 \%$."

For the purposes of my research, as a starting point, I will focus on the biologically determined male as given differences are minimal in sexual development at an estimated frequency of $1 \%$ or less.

I recognize the existence of socially constructed interpretations in discourse; actions, culture, politics and gender can sometimes conflict and constantly shift creating hegemony and power relations. This view of knowledge directly links to Ball's [6] review of Foucault's argument "we must make allowance for the complex and unstable powers whereby discourse can be both an instrument and an effect of power (Foucault 1982, 101)" (p. 2). Dominant discourse also existed in the patriarchal society whereby the feminist movement challenged and achieved much progress. This movement has achieved the inclusion of lesbian, gay, bisexual, transgender and queer (LGBTQ) but as it progresses it may be inadvertently disrupting equality aims preventing the masculine stereotypical male voice to be heard. I will challenge the current discourse surrounding the vulnerability of boys in a seemingly feminized environment which could potentially subjugate masculinity if gender discourse continues on its current trajectory. Furthermore, much of the feminist argument is based on a historical or patriarchal lens that Farrell [14] argues is rooted in Marxism and civil rights movements which were based in the 18th to middle 19th century and needs updating to the 21 st century. In fact, the masculine stereotypical versus nonmasculine stereotypical traits amplified in boys has created a massive debate that triggered pro feminists to suggest men need to explore their feminine side to ensure society can be safe.

There are two strong debates which exist: one representing pro-feminism and the other consistently coined the backlash against feminism. Along with several scholars the thought of researching masculine stereotypical or even hegemonic boys becomes a controversy fueled by arguments put forth such as by Lingard and Douglas [31] "At the same time we acknowledge that those 'toxic' aspects of hegemonic masculinity are dangerous to boys themselves, as well as to other boys practicing different, sometimes, marginalized or subordinated masculinities, and to many girls and women" (p. 5). They further caution, "This danger is evident...in the suicide rates for young men, in their risk taking behaviors and in the road toll, in their use of violence and in sexual and other forms of harassment of girls and other boys, including homophobia" (p. 5). My research is not to deny the existence of these issues but rather to understand which boys are not performing well in literacy and focus on that group; regardless of their status of their masculinity as it is important to ensure all boys have a voice (see for example Keddie [29]). Furthermore, several studies exist that center on boys, masculinities, literacy and schooling (see for example, studies by Frank et al. [18]; Martino and Berrill [34]; Nayak [38]). However, these argue to disrupt or interrogate masculine stereotypical boys in ways that suggest these boys do not conform to the normative gendered view of society or schooling and need reform; this in itself promotes exclusion not gender equity. Furthermore, this type of reasoning can limit research and shortchange or deny masculine stereotypical boys' reading or video game interests that may improve in-school literacy.

There is no doubt that hegemonic (dominating, violent) forms of masculinity are not acceptable in schooling or society but that does not equate to all boys. This has been countered by activists in the field such Sommers ([48], [49]). Sommers [49] highlights this concern that "no one denies that boys' aggressive tendencies much be checked and channeled in constructive ways. Boys need discipline, respect, and moral guidance. Boys need love and tolerant understanding. They do not need to be pathologized" (p. 14). In fact, Sommers [49] argues "boys are being wrongly "masculinized"... inspiring a movement to "construct boyhood" in ways that will render boys less competitive, more emotionally expressive, more nurturing-more...like girls" (p. 44). 
In exploring research on the boys' literacy gap, I found numerous studies exist such as those investigated by Martino and Resai-Rashti [35]; however, these focus on ethnicity (race and class inequality and social economic status rather than boys. My research does not deny that racial minority and economic status contribute widely to the problem, however the underlying weakness is still boys and gender equity. In fact, Sommers [50] claims, "race and class further exacerbate the problem of male underachievement, but...in all economic and ethnic groups girls out-perform boys. Young women from poor neighborhoods in South Chicago do much better than the young men from those neighborhoods...Gender is a constant" (pp. 191-192).

It is with this insight and lack of research surrounding masculine stereotypical boys' needs that I originated the source of my investigation.

\section{Epistemology}

My epistemological view is based on subjectivism. Reality is subjective or constructed based on individuals' perceptions. Varying degrees of interpretations of different people in the world can foster power relations. People in the world are not homogeneous and if controlled to become this way there is a loss of self-identity. Foucault [17] in discipline and punish emphasizes the homogeneity and the impacts on people in society stating "the power of normalization imposes homogeneity" (p. 184).

Through my post-structural feminist lens I will critically argue how the boys' literacy gap may be a by-product of current power discourse with the progress of the feminist movement and the lack of boys' external interests to be integrated in curriculum, namely video gaming. Derrida [12] argues that in order for justice to occur it "demands that the voice of every student be heard" (p. 7). Part of searching for that voice will include a process of deconstruction of meaning to explore the contextual relationships that exist. This critical examination of current discourse involves cognitive dissonance (disequilibrium) to rebuild any existing disconnects in gender equity and examines outof-school video game literacy activities engaged by grade 10 stereotypical masculine boys to their in-school literacy practices.

\section{Literature Review}

This paper addresses the research exploring the literacy activity of the typical male profile of boys engaging in video game usage. Literature shortcomings exist for utilizing video games in the classroom. This lack of research is due to extensive debates questioning literacy content in video games or social issues perpetuating from the use of video games. Overall scholar research positions two main players: First, Gee [20, 21, and 22] advocating literacy content and second, critics who limit identifying any plausible means of students' developing literacy skills to be transferred into the classroom. Sanford and Madill [45] caution "the hegemonic masculinity model looms large in most of the games the participants report playing regularly...we worry that they are reinforcing the binary: that relegates females to subordinate positions" (p.300).

This lack of research is the result of misperception of the literacy content in video games dominated by violence and misogyny which may influence a variety of social issues coming from their use. Most popular games, however, are designed with storylines. Using a critical feminist poststructural lens, I intend to fill some of these gaps by identifying existing power relations to introduce new perspectives to balance gender and raise pedagogical awareness of video game literacy.

\section{Theories informing Research}

The theoretical foundation informing my research is based on shortcomings or rather disconnects apparent in the current field of research to address boys' literacy gap and gender equity. As I deconstructed my research problem of addressing the boys' literacy gap through video technology I began to explore it from different perspectives and angles to understand elements of why it was occurring: Was it the teaching models? Was it a lack of the male voice? Was it the masculine stereotype and how it fit into the social micro culture of the school and society? Was it simply boys' selfidentification as a masculine stereotype and avoidance of humanity subjects which are perceived as feminine? From these, what was preventing the literacy performance from improving?

Simply put, as my research problem bridges two distinct disciplines of Technology and Gender Equity, it explores four major 
disconnects: 1) feminism agenda used today vs. historical stakehold (feminists vs. male activists); 2) theoretical pedagogy - teaching models to address the literacy gap - teacher centered pedagogy vs. student centered; 3) literacy performed by masculine stereotypes (inschool vs. out of school video gaming and gamed based activity online network community learning); 4) masculine stereotype vs. nonmasculine stereotype and how it fits in society and school micro-culture.

My first step was to explore the existing theoretical model which would inform and align the teaching or integrating of video technology for literacy specifically for boys' needs and their voice. The model used widely by scholars and beneficial for bridging technology with learners is a multiliteracy and technology model Technological, Pedagogical Content Knowledge (TPCK) designed by Mishra \& Koehler's as described in the American Association of Colleges for Teacher Education [4]. The model integrates learning in the classroom in a different way but also shared a major research shortcoming to incorporate a student voice and learner perspective to address critical literacy for multiliteracy. The TPCK model specifically integrates technology in a flexible way in the classroom allowing for constant assessment of the learner's understanding of content and ways of adjusting the pedagogy to help the learner, while considering learner's prior knowledge. Emphasis is placed on teachers as curriculum designers to facilitate learning without incorporating a student perspective and was not specific to video game technology in the classroom. To bridge the two disciplines, while considering the male voice, I will draw from the TPCK model but will devise a revised model which considers the learner's (boys) perspective and voice with game technology for improving literacy. In fact, Frank et al. [18], recognize the need for reconnecting pedagogy with students "the debate about boys' underachievement continues, often with little analysis of, or reflection upon historical records of achievement and their implications for connections between masculinity and pedagogy" (p. 122).

To contextualize meaning for my research position, I needed to draw on several theories as one was not sufficient to inform my research and exploration of disconnects in literature, theoretical models and literacy performance gaps and gender perception. I began to navigate a conceptual map starting with connectivism. As a bridging mechanism, this made sense to use connectivism as it relates to a "set of connections formed by actions and experience...the activities we undertake when we conduct practices in order to learn are more like growing or developing ourselves and our society in certain (connected) ways" (Downes, [13], p. 85). This could have been applied to how males connect their out of school literacy practices using video games to their in-school literacy performance. However, I found that it didn't relate well to cognitive behavior and literacy skills based on social activities of boys in their use of video games which they could transfer to in-school practice. It also didn't align to my constructivism ontology regarding people and values and couldn't address other disconnects I wanted to explore such as feminism disconnected to twenty-first century needs to include masculine type boys. Connectivism as a theory relates more to online network interaction experiences (Downes, [13]; Shaviro [46], Cromer [11]; Hawthorne \& Klein [25], McLuhan [36]) rather than activity based learning and social networks.

This led me to investigate the theoretical aspects of Vygotsky's [53] social activity based learning. The reason is that boys engage in video gaming which includes a component of play and socialization. Gee [20] emphasizes "whether they play alone or together, the enterprise is social since almost all players need to get and share information about the games in order to become adept at playing them" (pp. 91-92). Learners react cognitively as Alexander [3] claims "some gamers are actively engaged in developing high-level literacy skills such as literacy reflectivity, trans-literacy connections, collaborative writing, multicultural literacy awareness, and critical literacy development" (p. 37).

For the gender equity component of my research study, I needed a theory to support my critical examination and challenge of current feminist discourse addressing gender equity and literacy performance for boys. Piaget's [43] theory of cognitive dissonance seemed the optimum choice. My reasoning was to expose and isolate understanding and application of content literacy of video games due to the wide scholar rejection/debate of stereotypical themes and expand feminist poststructuralism to consider the needs of men in the 21 st century, fostering gender equity. However, these disconnects are based on cultural and social powers and hierarchies which need to be modified or removed in order for harmony and 
equity to take place. At first, there were major benefits of using cognitive dissonance theory (Piaget [43]) as it relates to individuals who are biased (perhaps in relation to masculine stereotypical boys), seek balance between their experience and reality so they can construct new meanings. This causes disconnects as people retain their constructs from experience, culture and beliefs. Piaget [42] refers to humans being interactive on a social basis "since man is essentially a socialized being... This accounts for the considerable amount of research into the nature and extent of social influences, communication conflicts" (p. 42). In Piaget's earlier work [43], he refers to disequilibrium or cognitive dissonance in society which when evaluated and logically reasoned can remain stable or in harmony.

Since this source consists of a nonbalance of the assimilating and of the accommodation, the final evaluation involves a judgment dealing with success. First there is the assimilation of data, and afterward there is the possibility of the comprehension of new relations owing to the reequilibration of the assimilation and the accommodation, and to the information taken from initially disturbing elements and finally integrated into readapted behavior. (p. 29)

Piaget [43] later states "by no means does an equilibrium constitute a stopping point, since any finished structure can always give rise to new requirements in fresh substructures or to interpretations in greater structures" (p. 30). However, shortcomings in Piaget's [43] theory were later discovered by Festinger [15] who theorized that cognitive dissonance or disequilibrium cannot be measured as it is based on behavior and never really changes or achieves equilibrium status due to pre-history or experiences. In his work, Festinger [15] found "amount of dissonance that exists after a decision has been made is a direct function of the number of things the person knows that are inconsistent ...the greater the conflict before the decision, the greater the dissonance afterward" (p.5). This calls into question the suitability of adopting this theory to my research and presented a further dilemma in which to find an adaptable theory to understand perceived issues of feminism vs. male attitudes. It also presented a challenge because much of the feminist argument is based on a historical or a patriarchal lens that Farrell [14] argues is rooted in Marxism and civil rights/voting movements which were based in the 18th to middle 19th century and need updating to the 21 st century.
So, how could I find a theory which deconstructs or brings understanding to that mode of thinking? One major theorist who advocates the negative individual and societal impacts of hierarchies is Bourdieu (Swartz [52]). Both disciplines video game technology (under debate by scholars) and gender equity (accepting the masculine stereotype) seemed to represent a perceived symbolic power or hierarchies theorized by Bourdieu (Swartz [52]).

Bourdieu's (Swartz [52]) main theoretical framework is grounded in deconstructing class and societal structures/hierarchies based on culture and power related to class structures (habitus). This class division is a shortcoming in relation to my research; however, the underlying framework of symbolic power can inform my research.

\section{Methodology}

Specifically my research relates to accounting for the male voice. My methodology is based on feminist poststructuralism which rests within critical theory exposing power and societal relations existing in discourse. Poststructuralism seeks to explore, challenge and deconstruct hegemonic power relations fostered by dominant discourse. Foucault [16] highlights this point in his archaeology of knowledge "the major types of discourse... which tend to create certain great historical individualities...are always themselves reflexive categories, principles of classification, masculine stereotypical rules, institutionalised types: they, in turn, are facts of discourse" (Ch. 1 The unities of discourse).

Throughout history the aim of the subordinated feminists needed to move toward reducing the power of the patriarchal society (dominated by masculine stereotypical view of masculinity). Lather [30] explains feminism has had to go through different stages in order for rights to be gained. I believe a point of feminism maturation has occurred or is forthcoming. I am not advocating as reductionist feminist; however, feminism is not meant to be vertically linear, it should be evolving and open to addressing fair social change, equitable to all gender: male, female and LGBTQ.

Using feminist poststructuralism as a lens the concern is about exposing power relations that exist in discourse and societal relations with the aim to discover a balanced view so all voices can be heard. In fact, Weedon [54] argues "for a 
theoretical perspective to be politically useful to feminists...it should not deny subjective experience, since the ways in which people make sense of their lives is a necessary starting point for understanding how power relations structure society" (p.8). Disconnects can occur as circumstances and individuals who exist in the society continuously change along with political and social agendas to support those individuals. Weedon [54] expresses this idea as "feminism is a politics...directed at changing existing power relations between women and men in society" (p.1). But also Weedon [54] counters this with the understanding that in society each individual is subjective which can cause conflict: "individual women and men are often the agents of oppression...we need a theory which can explain how and why people oppress each other" (p. 3.).

Using a post-structural feminist lens within critical theory is salient to my own research and epistemology of constructivism and subjectivism. Weedon's [54] direction incorporates the voice of both women and men along with her understanding that power dynamics exist in society that perhaps need to be adjusted. This also aligns well to the underpinning of Bourdieu's (Swartz [52]) symbolic power in my research. Disconnects can occur as circumstances and individuals who exist in the society continuously change along with political and social agendas to support those individuals. Weedon [54] expresses this idea as "feminism is a politics...directed at changing existing power relations between women and men in society" (p.1).

This aligns to the Bourdieu's reasoning of symbolic power which can influence and perhaps alter institutions. In fact, Swartz [52] highlight's Bourdieu's belief that "power is not in words or symbols per se but in the 'belief in the legitimacy of the words and of him who utters them"" (p. 88). For Bourdieu, "symbolic power resides not in the force of ideas but in their relation to social structure...defined in and by a determinate relationship between those who exercise this power and those who undergo it" (Swartz [52], p. 88).

My methodology is based on feminist poststructuralism which rests within critical theory exposing power relations existing in discourse and societal relations. To better understand the social hierarchies and power struggles that exist, I rely on theories developed by Bourdieu such as social hierarchies and symbolic power which can and sometimes do have an influence on the ways boys perform their masculine stereotypical or non traits and the way in which the institutions (schools) adopt these hierarchies (Swartz [52]. These social hierarchies exist due to the way individuals who live in the world construct their realities and often these diverse perspectives are not shared between and among people as they interact. Bourdieu claims "Culture includes beliefs, traditions, values, and language; it also mediates practices by connecting individuals and groups to institutionalized hierarchies. Whether in the form of dispositions, objects, systems, or institutions, culture embodies power relations. Further, many cultural practices in the advanced societies constitute relatively autonomous arenas of struggle for distinction" (Swartz [52], p.1).

In fact, Bourdieu views hierarchies as "how cultural socialization places individuals and groups within competitive status hierarchies...how these social struggles are refracted through symbolic classifications, how actors struggle...to achieve their interests within such fields, and how in doing so actors unwittingly reproduce the social stratification order" ((Swartz [52], pp. 6-7). This resonates with how masculine stereotype boys are regarded as not conforming to school micro culture or somehow disassociated with gender. It is true that hegemonic males (dominant) can disrupt school culture; however, this generalization to masculine stereotypical boys is not setting an example of gender inclusion. Sommers [49] refers to observations by a London high school teacher, Martin Spafford "Boys feel continually attacked for who they are. We have created a sense in school that masculinity is something bad. Boys feel blamed for history, and a school culture has grown up which is suspicious and frightened of boys" (p. 57). Assumptions are continuously played out by feminist scholars regarding the exclusion of masculine stereotype boys' needs due to the over-generalization based on a fusion of definitions of hegemonic and masculine stereotype boys. Sommers [49] contends:

A small percentage of boys are destined to become batterers and rapists; boys with severe conduct disorders are at high risk of becoming criminal predators. Such boys do need strong intervention, the earlier the better. But this small number of boys cannot justify a gender-bias industry that looks upon millions of normal male children as pathologically dangerous. (p. 50)

Bourdieu's (Swartz [52]) theory informs this aspect of my research problem because it 
constitutes a symbolic power based on "the active role played by taken-for-granted assumptions in the constitutional and maintenance of power relations" (p. 43). In fact, feminist scholars suggest male teachers support masculine stereotypical boys' behavior by promoting sports' discourse (see Martino and Berrill [34]). This seems an ambiguous attempt to label these boys as hegemonic and at risk of performing violence and domination. This form of labeling in discourse represents how symbolic power can segregate individuals into class distinctions which does not promote gender equity. As Bourdieu states "this social function of the classification logic of symbolic representations generates, therefore, a political effect to the extent that the social groupings identified are hierarchically differentiated and therefore legitimated" (Swartz [52], p. 87). It is true that Bourdieu applied his reasoning to social class and hierarchies, but it also represents the symbolic power of inequity - where in history this represented a patriarchal society, now in effect a feminist hierarchy is being formed, by symbolic power. The risk is normative masculine stereotypes may be marginalized in schools in response to self-interested feminists drawing from selective equity practices. In fact, a symbolic power can produce reality or a new hierarchy where feminists suggest and attempt to define their view of gender equity which displaces and excludes masculine stereotypes. Bourdieu (Swartz [52]) cautions "classes-onpaper" can become 'classes in-reality' only if there is symbolic and political work to give them actual identity and mobilization" (p. 45). Sommers [49] echoes this with her claim that "reformers who promote their...notion of equality in our schools represent no one but themselves... and many American educators have become persuaded that eliminating "masculine stereotypes" is prerequisite to fulfilling the promise of a democratic equality" (p. 98).

Farrell [14] refers to feminism working through a historic lens based on Marxism and oppression relating to civil rights' movements which needs to be reassessed for addressing issues in the $21^{\text {st }}$ century. This type of discourse leads to a dichotomy of men vs. women without supporting a balanced perspective. Through my poststructural feminist lens I will critically argue how the boys' literacy gap may be a by-product of current power discourse with the feminist movement and the lack of boys' external interests to be integrated in curriculum. Within this critical paradigm I want to balance both female and male subjective voices. Finding the male voice will include a process of meaning deconstruction to explore existing contextual relationships. In addition, in consideration of 21 st century societies, I question whether the tenets of feminist poststructuralism can adequately address contemporary issues and ways of knowing how men and women interact, given agendas rely on a Marxism and civil rights' foundation (Molyneux [37]). Weedon [21] advocates "feminist poststructuralism takes much from Marxist discourse" (p. 31). However, Bourdieu [7] "challenges both the Marxist theory of superstructure and idealist views of cultural life by proposing a theory of intellectual that emphasizes the specific symbolic interests that shape culture production" (p. 94). In fact, Swartz [52] highlight's Bourdieu's main complaint that "the educational system is one example of a cultural field obtaining considerable autonomy as a result of its capacity to control the recruitment, socialization, and careers of actors, and to impose its own specific ideology" (p. 128). Whereby, feminism discourse in schools can shape a micro culture that can often be damaging to students' voice and action or performance as masculine stereotypes. Lingard \& Douglas [31] dismiss the view put forth by male activists to develop male-oriented curriculum and hire more teachers and that "schools are failing boys" (p. 53). Furthermore, Lingard \& Douglas [31] reject reform policies for boys' schooling as promoting hegemonic behaviors for masculine stereotype boys and argue:

Some of the problems that boys experience in schools...stem from their natural propensity to more active and aggressive than girls...Part of the solution must therefore be the remasculinization of schooling. (We would note the dangers here of such approaches reinforcing hegemonic forms of masculinity). However, there are also calls for boys to be encouraged more sensitive and caring models of manhood which would enable them to resist the enormous cultural pressure for them to conform to hegemonic versions of masculinity. (pp. 54-55)

In fact, Weedon [54] explores the notion of extending theory to assimilate equity feminism (see Gardiner [19]; Holter [26]; Lorber [32]; and Sommers, [48]) suggesting the "abolition of the categories 'woman' and 'man' as they currently exist and the opening up of all social ways of being to all people" (p.18). This extreme notion 
to eliminate categories, risks further ambiguity for gender (does it include males? LGBTQ?) and perpetuates a homogeneous society. Politically this would not legitimate any group to have privilege or voice to be heard. Foucault [17] cautions "the power of normalization imposes homogeneity" (p. 184). However, Holter [26] recognizes the need for men's participation within gender dynamics of society to promote equality "the stronger the framework of equality, allowing research not just into gender and women but, even more controversially, men as gendered persons and the wider role of societal institutions, the better the chance of grounded theory in a positive sense" (p. 16).

\section{Conclusion}

The intent of the study is to address potential literacy value in video gaming engaged by masculine stereotypical male high school students in and outside of school to understand social inequities experienced (potentially caused from feminism issues) which may be leading to boys' lower literacy levels. Part of my current study and future planned research will examine the ways boys learn and interact with other gamers in the surrounding networks. The anticipated research findings will discover typical male students' out-of-school active interest in video gaming and surrounding networks which embed literacy components that can be transferred to in-school literacy practices for Ontario curriculum. In addition, this research will contribute to current field of literature which lacks research about the uses of video gaming and surrounding networks in the classroom to address literacy gaps. This current research will enable my future research path in developing awareness for curriculum and building new discourse to redress the gender balance (inclusion of masculine stereotypical male). I intend to fill some gaps by identifying existing power relations to introduce new perspectives to balance gender and raise pedagogical awareness of video game literacy.

I have come to understand that in the midst of the gender struggle masculine stereotypical males have been somewhat displaced from socially constructed gender views. Therefore, my research will be open to hear all voices to foster a balanced social equity. This will also lead to future research to continue to explore the male perspective where I will incorporate the views of Farrell [14] and Kaufman [28]. I will also examine Kaufman's AIM framework [28]. 


\section{References}

[1] Ajayi, L. (2011). A multiliteracies pedagogy: Exploring semiotic possibilities of a Disney video in a third grade diverse classroom. The Urban Review, 43(3), 396-413. doi: 10.1007/s11256-010-0151-0

[2] Akkerman, S., Admiraal, W., \& Huizenga, J. (2009). Storification in history education: A mobile game in and about medieval Amsterdam. Computers \& Education, 52(2), 449-459. doi: 10.1016/j.compedu.2008.09.014

[3] Alexander, J. (2009). Gaming, student literacies, and the composition classroom: Some possibilities for transformation. College Composition and Communication, 61(1), 35-63. Retrieved from http://search.proquest.com.proxy1.lib.uwo.ca/do cview/220704712?accountid=15115

[4] American Association of Colleges for Teacher Education. (2008). Handbook of technological pedagogical content knowledge (TPCK) for educators. New York: Published by Routledge for the American Association of Colleges for Teacher Education.

[5] Apperley, T., \& Beavis, C. (2011). Literacy into action: Digital games as action and text in the English and literacy classroom. Pedagogies, 6(2), $130 . \quad$ Retrieved from http://search.proquest.com.proxy1.lib.uwo.ca/do cview/869913792? accountid=15115

[6] Ball, S. J. (2010; 1990). Foucault and education: Disciplines and knowledge. London; New York: Routledge.

[7] Bourdieu, P. (1990). In other words: Essays toward a reflexive sociology [Choses dites. English.]. Oxford: Polity.

[8] Brochu, P., Gluszynski, T., \& Knighton, T. (2010). Measuring up: Canadian results of the OECD PISA study: The performance of canada's youth in reading, mathematics and science: 2009 first results for canadians aged 15. (Research Report No. 4). Ottawa, Ont.: Human Resources and Social Development Canada, Statistics Canada. Retrieved from http://publications.gc.ca/collection_2010/statcan
/81-590-X/81-590-x2010001-eng.pdf (Access date: 12 Oct 2012)

[9] Bourdieu, P. (2001). Masculine domination (Nice, R., Trans.). Stanford, Calif.: Stanford University Press. (Original work published 1998).

[10] Centre for gender-based biology in the University of California (2013). Retrieved from: http://gendercenter.genetics.ucla.edu/Current_Pr ojects/Current_Projects.html (Access date: 10 Feb 2013)

[11] Cromer, A. H. (1997). Connected knowledge: Science, philosophy, and education. New York: Oxford University Press.

[12] Derrida, J. (1997). Of grammatology [De la grammatologie.English] (Correct ed.). Baltimore: Johns Hopkins University Press.

[13] Downes, S. (2012). Connectivism and Connective Knowledge. Essays on meaning and learning networks. National Research Council Canada.

[14] Farrell, W. (1993) The Myth of Male Power. New York, NY: Simon and Schuster.

[15] Festinger, L. (1964). Conflict, decision, and dissonance. Stanford, Calif., Stanford University Press

[16] Foucault, M. (1969). The archaelogy of knowledge. Retrieved from http://www.marxists.org/reference/subject/philos ophy/works/fr/foucault.htm (Access date: 8 March 2013)

[17] Foucault, M. (1977). Discipline and punish: The birth of the prison (1 American ed.). New York: Pantheon Books.

[18] Frank, B., Kehler, M., Lovell, T., \& Davison, K. (2003). A tangle of trouble: Boys, masculinity and schooling--future directions. Educational Review, 55(2), 119-133. doi: $10.1080 / 0013191032000072173$

[19] Gardiner, J. K. (2005). Chapter 3: Men, Masculinities, and Feminist Theory. Kimmel, M. S., Hearn, J., \& Connell, R. (Eds.), 
Handbook of studies on men \& masculinities. Thousand Oaks, Calif.: Sage Publications

[20] Gee, J. P. (2007). Good video games and good learning: Collected essays on video games, learning, and literacy. New York: P. Lang.

[21] Gee, J. P., \& ebrary, I. (2003). What video games have to teach us about learning and literacy (1st ed.). New York: Palgrave Macmillan.

[22] Gee, J. P., \& Levine, M. H. (2009). Welcome to our virtual worlds. Educational Leadership, 66(6),48. Retrieved from http://search.proquest.com.proxy1.lib.uwo.ca/do cview/224838970?accountid=15115 (Access date: 20 Mar 2013)

[23] Gros, B. (2007). Digital games in education: The design of games-based learning environments. Journal of Research on Technology in Education, 40(1), 23-38. Retrieved from http://search.proquest.com.proxy1.lib.uwo.ca/do cview/274710337? accountid=15115

[24] Guba, E. \& Lincoln, Y. (1994). Chapter 6: Competing Paradigms in Qualitative Research. Denzin, N. K., \& Lincoln, Y. S. (Eds.), Handbook of qualitative research. Thousand Oaks: Sage Publications.

[25] Hawthorne, S., \& Klein, R. (Ed.). (1999). Cyberfeminism: Connectivity, critique. Melbourne: Spinifex.

[26] Holter, O. G. (2005). Chapter 2: Social Theories for Researching Men and Masculinities: Direct Gender Hierarchy and Structural Inequality. Kimmel, M. S., Hearn, J., \& Connell, R. (Eds.), Handbook of studies on men \& masculinities. Thousand Oaks, Calif.: Sage Publications

[27] Huizenga, J., Admiraal, W., Akkerman, S., \& Dam, G. (2009). Mobile game-based learning in secondary education: Engagement, motivation and learning in a mobile city game. Journal of Computer Assisted Learning, 25(4), 332-344. doi: 10.1111/j.1365-2729.2009.00316.x

[28] Kaufman, M. (2003) AIM (Addressing and Involving men) Framework.
[29] Keddie, A. (2008). Playing the game: Critical literacy, gender justice and issues of masculinity. Gender and Education, 20(6), 571583. Retrieved from http://search.proquest.com.proxy1.lib.uwo.ca/do cview/61991849? accountid=15115

[30] Lather, P. (1991). Getting smart: Feminist research and pedagogy within the postmodern. New York: Routledge.

[31] Lingard, B., \& Douglas, P. (1999). Men engaging feminisms: Pro-feminism, backlashes and schooling. Buckingham England; Philadelphia: Open University Press.

[32] Lorber, J. (1994). Paradoxes of gender. New Haven: Yale University Press.

[33] Love, K., \& Hamston, J. (2003). Teenage boys' leisure reading dispositions: Juggling male youth culture and family cultural capital. Educational Review, 55(2), 161-177. doi: 10.1080/0013191032000072209

[34] Martino, W., \& Berrill, D. (2003). Boys, schooling and masculinities: Interrogating the 'right' way to educate boys. Educational Review, 55(2), 99-117. doi: $10.1080 / 0013191032000072164$

[35] Martino, W., \& Rezai-Rashti, G. (2013): 'Gap talk' and the global rescaling of educational accountability in Canada, Journal of Education Policy, doi:10.1080/02680939.2013.767074 http://dx.doi.org/10.1080/02680939.2013.76707 4

[36] McLuhan, M. (1964). Understanding media: The extensions of man. New York: McGraw-Hill.

[37] Molyneux, S. (Producer). (2013, February 17). Dr Warren Farrell Hosts the Freedomain Radio Sunday Call In Show [Video podcast]. Retrieved from http://youtu.be/xRiKRIkp7O0

[38] Nayak, A. (2003). 'Boyz to men': Masculinities, schooling and labour transitions in de-industrial times. Educational Review, 55(2), 147-159. doi: $10.1080 / 0013191032000072191$ 
[39] Neuman, L. W. (2006). Social research methods: Qualitative and quantitative approaches (6th ed.). Boston, MA: Pearson.

[40] New London Group. (2000). A pedagogy of multiliteracies: Designing social futures. In B. Cope \& M. Kalantzis. (Eds.), Multiliteracies: Literacy learning and the design of social futures. London; New York: Routledge.

[41] OECD (2010), PISA 2009 at a Glance, OECD Publishing. Retrieved from http://dx.doi.org/10.1787/9789264095298-en

(Access date: 12 Oct 2012)

[42] Piaget, J. (1973; 1970). Main trends in psychology. -. London: Allen and Unwin.

[43] Piaget, J. (1977). The development of thought: Equilibration of cognitive structures [Equilibration des structures cognitives, 1896. English]. New York: Viking Press.

[44] Sanford, K., \& Madill, L. (2006). Resistance through video game play: It's a boy thing. Canadian Journal of Education, 29(1), 287-306,344-345. Retrieved from http://search.proquest.com/docview/215378045? accountid $=15115$

[45] Sanford, K. \& Madill, L. (2007). Understanding the power of new literacies through video game play and design. Canadian Journal of Education, 30(2), 432-455. Retrieved from

http://search.proquest.com/docview/215370704? accountid=15115 (Access date: 13 Nov 2012)

[46] Shaviro, S. (2003). Connected, or, what it means to live in the network society. Minneapolis, MN; London: University of Minnesota Press.

[48] Sommers, C. H. (1994). Who stole feminism: How women have betrayed women (1 Touchone, ed.). New York: Simon \& Schuster.

[49] Sommers, C. H. (2000). The war against boys: How misguided feminism is harming our young men. New York: Simon \& Schuster.

[50] Sommers, C. H. (2009). The war against boys: Has it ended? Thymos, 3(2), 189-193. http://search.proquest.com/docview/203176085? accountid=15115

[51] Steinkuehler, C. (2010). Video games and digital literacies. Journal of Adolescent \& Adult Literacy, 54(1), 61-63. Retrieved from http://search.proquest.com.proxy1.lib.uwo.ca/do cview/750429343? accountid=15115

[52] Swartz, D. (1997). Culture \& power: The sociology of Pierre Bourdieu. Chicago: University of Chicago Press.

[53] Vygotsky (1978). Readings on the Development of Children. From Mind and Society (pp.79-91). (2nd ed.) Gauvain \& Cole (Eds.). Cambridge, MA: Harvard University Press.

[54] Weedon, C. (1997). Feminist practice \& poststructuralist theory (2nd ed.). Oxford, UK; Cambridge, Mass.: Blackwell Publishers. 